\title{
GIZZARD SHAD (DOROSOMA CEPEDIANUM) EXPANSION AND REPRODUCTION IN THE UPPER COLORADO RIVER BASIN
}

\author{
Sam T. Finney ${ }^{1,2}$ and Mark H. Fuller ${ }^{1}$
}

\begin{abstract}
Gizzard shad (Dorosoma cepedianum) were introduced into the Colorado River Basin circa 1996 via an unintentional contaminated stocking. Gizzard shad were collected throughout much of the Upper Colorado River Basin in 2005, 2006, and 2007. These collections document a rapid range expansion of this introduced species and a threat to intact fisheries.
\end{abstract}

Key words: gizzard shad, Dorosoma cepedianum, Upper Colorado River Basin, range expansion.

Gizzard shad (Dorosoma cepedianum) are believed to have been accidentally introduced into the Colorado River Basin circa 1996 via a transbasin sport-fish stocking at Morgan Lake, New Mexico, an impoundment near the San Juan River. Detected in the San Juan River in June 2000 (Mueller and Brooks 2004), this species multiplied and spread through the San Juan arm of Lake Powell (Blommer and Gustaveson 2002) and then expanded up the Colorado River, where it was first detected in the Green River at Sand Wash nearly 419 km upstream of Lake Powell (river km 347.0; Utah Division of Wildlife Resources, unpublished data). By 2006, gizzard shad had ascended to the Gunnison River at the Redland Fish Ladder (river km 3.7; McAda and Burdick 2007a); to the Colorado River in areas at, and downstream of, Price-Stubb Dam (river km 303.0; McAda and Burdick 2007b); and to the Middle Green River (river km 347.6-453.8; Utah Division of Wildlife Resources, unpublished data). Gizzard shad were reported at Echo Park, Colorado, near the confluence of the Green and Yampa rivers (river $\mathrm{km}$ 537.5; U.S. Fish and Wildlife Service, unpublished data) by 2007. No collections were made prior to 2004 despite intensive sampling throughout most of the Colorado River Basin.

The source of these fish is most likely Lake Powell or natural reproduction within the river system by colonizers. Introductions by other mechanisms are possible but not likely.

These collections demonstrate the potential for a rapid range expansion by gizzard shad after their introduction into a new basin. Although specific information on adult gizzard shad movement is limited, the fish has been documented migrating en masse in lotic environments (Swanson 1932). Documented rapid expansion over a short time period and suspected river recruitment (Trina Hedrick, Utah Division of Wildlife Resources, personal communication) are causes for alarm.

Gizzard shad pose a threat to native and sport fisheries in the Upper Colorado River Basin. Mueller and Brooks (2004) identified many of these threats. The gizzard shad is the 1st introduced fish in the basin that is a filter feeder throughout its entire life history (Whitehead 1985), and it also thrives in both reservoir and riverine environments. Gizzard shad are known to numerically dominate fish communities (Noble 1981) and alter entire food webs (DeVries and Stein 1992). The recent introduction of gizzard shad and more recently burbot (Lota lota; Wyoming Game and Fish Department 2006a, 2006b) in the Green River Basin adds to the growing litany of nonnative fish competition and predation that threatens native fish recovery in the Upper Colorado River Basin (Minckley and Deacon 1991, Fuller et al. 1999, Tyus and Saunders 2000). Nonnative fish control and removal programs have increased efforts and expenditures during the past decade but thus far have been unsuccessful in controlling or removing unwanted species (Clarkson et al. 2005, Mueller 2005). The successful establishment and spread of yet more nonnative fish species further complicates

${ }^{1}$ U.S. Fish and Wildlife Service, Colorado River Fishery Project, 1380 South 2350 West, Vernal, UT 84078

${ }^{2}$ E-mail: sam_finney@fws.gov 
management of sport fisheries and efforts to recover native fish.

We thank the Recovery Program for the Endangered Fishes of the Upper Colorado River Basin for funding monitoring efforts. Gordon Mueller and 2 anonymous reviewers provided valuable comments on an earlier draft. Chuck McAda, Paul Badame, and Trina Hedrick provided data and other information.

\section{Literature Cited}

Blommer, G.L., and A.W. Gustaveson. 2002. Life history and population dynamics of threadfin shad in Lake Powell 1968-2001. Utah Department of Natural Resources, Division of Wildlife Resources Publication 02-23, Salt Lake City. 78 pp.

Clarkson, R.W., P.C. Marsh, S.E. Stefferud, and J.A. STEFFERUD. 2005. Conflicts between native fish and nonnative sport fish management in the southwestern United States. Fisheries 30:20-27.

Devries, D.R., AND R.A. Stein. 1992. Complex interactions between fish and zooplankton: quantifying the role of an open-water planktivore. Canadian Journal of Fisheries and Aquatic Sciences 49:1216-1227.

Fuller, P.L., L.G. Nico, AND J.D. Williams. 1999. Nonindigenous fishes introduced into inland waters of the United States. American Fisheries Society Special Publication 27, Bethesda, MD.

MCADA, C.W., AND B. BuRdick. 2007a. Annual operation and maintenance of the fish passage structure at the Redlands Diversion Dam on the Gunnison River: annual report to the Recovery Program for the Endangered Fishes of the Upper Colorado River Basin, Project Number C4b-RED. 2007b. Removal of smallmouth bass in the Upper Colorado River between Price-Stubb Dam near Palisade, Colorado, and Westwater, Utah. Annual report to the Recovery Program for the Endangered Fishes of the Upper Colorado River Basin, Project Number $126 \mathrm{a}$.

MincKley, W.L., AND J.E. Deacon, Editors. 1991. Battle against extinction: native fish management in the American West. University of Arizona Press, Tucson.

Mueller, G.A. 2005. Predatory fish removal and native fish recovery in the Colorado River mainstem: what have we learned? Fisheries 30:10-19.

Mueller, G.A., AND J.L. Brooks. 2004. Collection of an adult gizzard shad (Dorosoma cepedianum) from the San Juan River, Utah. Western North American Naturalist 64:135-136.

Noble, R.L. 1981. Management of forage fishes in impoundments of the southern United Sates. Transactions of the American Fisheries Society 117:480-487.

Swanson, G. 1932. A mid-winter migration of gizzard shad. Copeia 1932:34.

Tyus, H.M., AND J.F. Saunders, III. 2000. Nonnative fish control and endangered fish recovery: lessons from the Colorado River. Fisheries 25:17-24.

Whitehead, P.J.P. 1985. FAO species catalogue. Volume 7, Clupeoid fishes of the world (suborder Clupeioidei). An annotated and illustrated catalogue of the herrings, sardines, pilchards, sprats, shads, anchovies and wolf-herrings. Part 1 - Chirocentridae, Clupeidae and Pristigasteridae. FAO Fisheries Synopsis 125(7/1): $1-303$.

Wyoming Game and Fish Department. 2006a. Illegally introduced burbot expanding range on western slope. Public Press Release, 3 November 2006.

2006b. More burbot netted in Flaming Gorge Reservoir. Public Press Release, 24 November 2006.

Received 4 March 2008 Accepted 18 April 2008 